\title{
Teachers' Attitudes to Incorporation Digital Means in Teaching Process in Relation to the Subjects they Teach
}

\author{
https://doi.org/10.3991/ijep.v9i4.11064 \\ Ján Záhorec, Adriana Nagyová \\ Comenius University, Bratislava, Slovak Republic \\ Alena Hašková ( $\left.{ }^{\varpi}\right)$ \\ Constantine the Philosopher University, Nitra, Slovak Republic \\ ahaskova@ukf.sk
}

\begin{abstract}
The paper presents some of the empirical results of the research focused on identification of the ways the primary and secondary school teachers use interactive educational activities and digital means in their teaching practice in dependence on the subjects they teach. The main research question was whether the ways of the use of interactive educational activities and digital means are the same for all teachers, independently on the character of the subject they teach, or whether it depends on the taught subject. As the results have showed, the purposes significantly differ in dependence on the character of the taught subjects. In the paper, in more detail results for teaching natural science subjects and foreign languages are discussed.
\end{abstract}

Keywords-Efficiency of teaching, digital didactic means, interactive activities, teacher training, teachers` didactic technological competences.

\section{Introduction}

The use of modern digital technologies streamlines a range of activities, including teaching and learning processes. It is therefore a global trend to integrate digital technologies into school life at all levels of education [1, 2, 3]. As Anderson, van Weert and Duchâteau state [4], supporting learning and teaching processes by digital means can significantly improve quality of education by emphasizing such skills as critical thinking, decision-making and handling of dynamic situations, working in groups, or communicating effectively. On the other hand, effective integration of digital technologies into the system of education is a part of a complex system, and is influenced by many factors as e.g. teachers' attitudes towards the technologies, their skills to use these means in their teaching practice, nature of the subjects they teach, purposes they follow, personalities of their students.

The driving force and conceptual platform for introducing digital resources into educational practice in the Slovak Republic is the document of the Ministry of Education, Science, Research and Sport of the Slovak Republic entitled "Concept of Informatisation and Digitalisation of the Branch of Education with a View to 2020 
(DIGIPEDIA 2020)." This document specifies main aims of informatisation and digitalisation of the Slovak education system in five strategic areas: infrastructure development, optimization of electronic services, digitalisation of subject matter, digital skills and cooperation with employers (https://www.minedu.sk/). The success of incorporating relevant innovations and conceptual intentions into the educational process is largely dependent on the development of professional competences of teachers, in particular by developing their didactic-technological skills. This concerns both the (lifelong) education of teachers and the pre-graduate education of teacher trainees [5].

Modern digital resources are important tools for teachers when preparing for lessons, as well as during the lesson itself. The development of new digital learning materials and teaching aids, interactive learning software, and virtual learning environments all require teachers to have a certain level of didactic-technological competences to properly prepare for their implementation in lessons and not be afraid to use these resources within their teaching practice [6]. These facts must also be reflected in the pre-graduate training of teacher trainees, what makes it necessary to constantly innovate the curricula of the relevant parts of the pre-graduate teacher training study programs so that the teacher trainees are made aware of the benefits of teaching using the latest digital resources $[7,8,9]$. The question is how to design an optimal model for teacher trainees in didactic-technological competences, which particular tools and which aspects of their use in the teaching process should be accentuated. Finding answers to these questions has become a subject of research, financially supported by the Ministry of Education, Science, Research and Sport of the Slovak Republic. The main purpose of this research is to support the modernization and optimization of the professional didactic-technological competences and development of pre-graduate teacher training.

The starting point for this research has been a survey aimed at identifying teachers' attitudes at primary and secondary schools (ISCED 1 - ISCED 3) to use digital resources to teach different subjects in relation to different aspects of the lesson [10].

A question is for which purposes teachers use technical teaching means - mainly the newest digital ones - in their subject teaching. We were interested in which part of the teaching process teachers apply digital teaching tools, and with them connected interactive activities, to support teaching and learning processes. Is it the same for all subjects or are there some significant differences in dependence on the character of the taught subject? So the main research question for us was whether it is the same for all teachers, independently on the character of the subject they teach, or whether it depends on the taught subject. The results of this survey are presented below.

\section{Context of the Partial Research in an International Scale}

The issue of using digital didactic resources in teaching at primary and secondary schools has been discussed in a number of empirical researches [11, 12, 13, 14, 15, 16]. These surveys usually have a complex focus and work with data from statistical offices, or include a high number of respondents in the survey, and process data by means of quantitative statistical methods, while evaluating the data collected is aimed 
at using digital didactic resources in schools across subjects taught. It is important to realize that the educational contribution of digital didactic resources depends on the particular choice and implementation of the digital instrument in the teaching of a particular teaching discipline. Therefore, it is important to show teachers how to use the new digital technologies as effectively as possible, based on rational assessment of the particular part of the lesson, in which the use of these resources to accomplish appropriate learning achievements is effective and beneficial.

Dofková and Uhlírová [17] consider creating a stimulating environment as the main positive of digital didactic tools and their interventions in the educational process. As stimulating they identify the environment that is appealing for pupils, attracts them and raises their interest in learning material, and therefore we talk about the motivational potential of these environments. The use of various applications of digital technologies has become a standard in our lives, so in terms of "novelty", the motivational potential of digital technologies for pupils is no longer as high as for example ten years ago, but given that these technologies represent a "normal part" of pupils' lives, learning based on their use continues to enjoy considerable popularity. So, if a teacher appropriately chooses the right digital resources, he can amplify the motivational aspects of the lesson.

Conclusions of numerous studies [18, 19, 20, 21, 22] confirm that the use of digital didactic tools in teaching and finding information through them, encourages pupils (in addition to motivational aspects) to be more interested in learning and encourages also ongoing pupils` activity.

Another indisputable benefit of using digital technologies in teaching is the fact that they allow to get immediate feedback, allowing pupils to be immediately informed of their success or failure in the activity [23]. In a traditional lesson, a pupil often receives late feedback (or does not receive it at all), while a long period of getting feedback, such as in homework or exams, can have negative influence on memorising incorrect information in terms of learning concepts or ways of solving learning tasks. Audience response systems (clickers) or interactive exercises can give the pupil, as well as the teacher, feedback immediately, thus helping to identify early weaknesses and return to misunderstood learning issues. As stated by Uhlírová [24], the involvement of digital resources in mathematics teaching has great potential. For example, in the case of design or research tasks, a pupil may be guided by a didactic computer / tablet application to search for an error, to solve analogous tasks, or to observe the effect of changes in parameters on the outcome of a solution. Also, modern laboratory measurement systems (PASCO / VERNIER) designed to support science education (chemistry, biology, physics, geography), especially if they are controlled directly by pupils during lessons, can help pupils to articulate and explain theoretical knowledge, which under normal circumstances is difficult to imagine. As Havelka [25] points out, pupils can easily understand the phenomena that were not clear from the textbook and make the teaching itself more attractive by using interactive electronic activities and experiments.

At the same time, however, it should be remembered that the implementation of digital technologies into teaching and learning processes does not have only positive impact [26]. Vaníček [27] points out that there is a concern of public teachers ' body 
that digital technologies will not become a „crutch“ replacing the skills and knowledge acquired during teaching, so that teaching of subjects based on computer / tablet applications does not become just another platform leading children to consume technology. In this context, he reckons it is risky to target computer application as dominant learning technique instead of acquiring educational content.

The research survey conducted by Brotánková [28] at selected basic schools in the Czech Republic (i.e. according to ISCED 2 at lower secondary schools) showed that the most common way of using modern digital resources in teaching Czech language and literature is practice. Pupils either work on the interactive whiteboard or have spelling exercises omitted to fill in the correct prefixes, suffixes, phonetic groups, or practice selected / related words. The most common phases of the lesson in which technologies are used are motivation, evocation and consolidation. Use of these technologies in the final phase of the lesson to summarize the curriculum is minimal. The survey also revealed that most teachers using digital teaching aids use them to present illustrative materials (images as basis for description when writing essays), play movies (in literature), or project language exercises (grammar).

Most teachers with longer teaching experience have come into contact with digital didactic tools during their teaching practice. A large percentage of teachers are selfeducated in this area, but some have received further content-related training provided by one of the relevant educational institutions (providers). As Kostrub [29] points out, graduate teachers are already doing quite well with the use of modern technology, but as part of their pre-graduate training, faculty students (teacher trainees) are still only marginally concerned with the use of modern digital didactic tools in teaching their subjects. Chromý [30] expresses concern about the teachers' ability to meet the increasing demands of society for the quality of teaching. Teachers need to consider methods that save time while ensuring that pupils gain as much knowledge as possible during lessons. Therefore, it is necessary to constantly modernize and rationalize teaching. Hlavaty [31] points out that the teacher must not only be prepared for the use of digital teaching resources but he also must want to use it. In this context, Hausner [32] talks about the problem of lack of motivation and self-confidence of teachers in dealing with interactive digital tools. The problem, he said, is also the low level of willingness of teachers to change traditional teaching methods. In his work, he comments on the "teachers' personal resistance to novelty". He refers to a survey conducted in 2007 with a group of three hundred Czech teachers: "Even then, teachers admitted that the main reason for their reluctance to use digital technology is not technical or material problems but their own constraints and limitations. Nowadays, no doubt, this problem has deepened."

Research conducted by Novák [33] also focused on the integration of digital resources and, in addition, web applications in basic school education (i.e. again according to ISCED - lower level of secondary schools). The results of this survey point to the most common use of digital resources in teaching subjects of the Mother Tongue, Mathematics, Foreign Language and History. On the contrary, the smallest support for teaching through digital didactic resources has been recorded in Physics. According to Novák [33], teachers have plenty of digital technologies available at the moment, but the digital literacy of teachers is low. Most teachers use interactive whiteboards and 
the internet for formal teaching, and they plan to continue using these tools (as they are confident to use only these tools). On the internet, they are mostly searching for fun or interesting content to diversify the lessons. In doing so, teachers are not able to fully exploit the potential of the technologies offered by these resources.

The empirical survey of Hladný [34] pointed to the fact that secondary school teachers most often use digital technologies to present new curricula, to supplement the teaching of a new material with illustrative demonstrations and, to a lesser extent, to test and validate pupils' acquired knowledge. At the same time, the results of his research show that grammar school teachers use digital technologies on average more often than secondary school teachers, where digital technologies are used rather passively.

\section{$3 \quad$ Research Sample and Methods}

The main question of our research was, as it is above-mentioned, in which part of the education process teachers apply digital means to support teaching and learning processes. Under the term teaching process in the stated research question, we do not mean strictly only a traditional lesson and its agenda. We understand it in a broader sense, as a continual process of education going through several lessons.

Two research questions resulted from the stated main question:

Q1: What are the purposes for which teachers use the digital means most often during their lessons?

Q2: Do the purposes for which teachers use the digital means during their lessons depend on the character of the taught subject?

Additionally to the research question Q2, a further question was stated:

Q3: Do the purposes for which teachers use the digital means during their lessons depend on the sub-category of the teaching staff to which a teacher belongs?

This research question is connected with the fact that Slovak legislation [35] distinguishes 7 categories of the teaching staff, which are teacher, vocational education teacher (supervisor), governess, teacher assistant, foreign lecturer, sport school/classroom trainer, accompanist and in relation to the regional schools (ISCED 1 - ISCED 3) the legislation categorizes teachers in three sub-categories, which are:

- Primary education teacher

- Lower secondary education teacher

- Upper secondary education teacher

Research sample consisted of 173 teachers - participants of teacher continuous edu-cation carried out from January 2018 to October 2018. The participants were primary and secondary school teachers representing primary and secondary schools in three of eight regions of Slovakia (Nitra region, Trnava region and Bratislava region, the regions for participants from which the continuous education was done). A detailed description of the research sample is summarised in Table 1. As main characteristics to describe composition of the research sample were used the factors GENDER, LENGTHS OF THE TEACHER'S TEACHING PRACTICE and 
CATEGORY and SUB-CATEGORY OF THE TEACHING STAFF to which the concerned teacher belongs according to the legislation rules. As Table 1 shows, a majority of the respondents $(50.29 \%)$ were teachers with teaching practice from 5 to 20 years.

To collect necessary research data the method of personal inquire was used. In frame of the personal inquire, the respondents responded de facto to the main research question (to its modification):

In which part of the lesson do you most often use interactive education activities (supported by digital means)?

choosing one from the five offered alternatives answers (the one that corresponded mostly to their teaching practice and experiences):

- To invoke greater motivation to learn

- To explain and exemplify new subject matter

- To fixate new subject matter

- To apply acquired knowledge

- To diagnose and grade pupils/students

Table 1. Description of the research sample (source: own research)

\begin{tabular}{|l|l|c|c|}
\hline \multicolumn{1}{|c|}{ Factor } & \multicolumn{1}{|c|}{ Factor category value } & $\begin{array}{c}\text { Absolute } \\
\text { number }\end{array}$ & $\begin{array}{c}\text { Relative } \\
\text { number }\end{array}$ \\
\hline \multirow{2}{*}{ Gender } & Male & 15 & $8.67 \%$ \\
\cline { 2 - 4 } & Female & 158 & $91.33 \%$ \\
\hline \multirow{2}{*}{$\begin{array}{l}\text { Length of teaching } \\
\text { practice }\end{array}$} & Up to 5 years (including) & 46 & $26.59 \%$ \\
\cline { 2 - 4 } & From 5 up to 20 years (incl.) & 87 & $50.29 \%$ \\
\cline { 2 - 4 } & More than 20 years & 40 & $23.12 \%$ \\
\hline \multirow{2}{*}{$\begin{array}{l}\text { Category of the teach } \\
\text { ing staff }\end{array}$} & Teacher & 156 & $90.17 \%$ \\
\hline \multirow{2}{*}{$\begin{array}{l}\text { Sub-category of the } \\
\text { teaching staff }\end{array}$} & Governess & 17 & $9.83 \%$ \\
\cline { 2 - 4 } & Teacher of primary level of education (ISCED 1) & 68 & $43.59 \%$ \\
\cline { 2 - 4 } & Teacher of lower level of secondary education (ISCED 2) & 69 & $44.23 \%$ \\
\cline { 2 - 4 } & Teacher of upper level of secondary education (ISCED 3) & 19 & $12.18 \%$ \\
\hline
\end{tabular}

Some of the respondents stated one answer (responded to the stated question only once) - this was a case of the respondents who teach only one subject or two subjects, but both of the same character. The rest of the respondents - those who teach subjects of different character (e.g. math and foreign language) stated two answers - one for each of the two taught subjects. According to the character, the subjects were classified into five categories:

- Natural science subjects

- Foreign languages

- Social science subjects

- Artwork and educational subjects

- Professional (vocational) subjects 
The above mentioned means that the total number 133 stated in Table 2 represents a sub-group of 133 teachers, from the total number of the 173 respondents, who teach either one or two natural science subjects.

An analogous situation is also presented for foreign language teachers (Table 3), where a subgroup of 107 teachers out of 173 respondents teaches one or two foreign languages.

Collected data were processed by means of the statistical analysis in dependence on the factors presented in Table 1. Analysis of the respondents' responses on the factor CATEGORY OF THE TAUGHT SUBJECT was based on contingency analysis, by means of which the measure of interdependence between two nominal variables is determined, i.e. it is used to analyse dependence of nominal variables, whether they are dependent of each other. Because of low expected frequencies, in frame of the non-parametric tests $c h i$-quadrat test of independence, to test significance of contingency coefficients, was not used. The only assumption of chi-quadrat validity is, that the expected frequencies are bigger or max equal to 5 (1).

$$
e_{i j}=\frac{r_{i} s_{j}}{n} \geq 5
$$

In some cases, this assumption was corrupted. Because of that, null hypotheses, to test independence of the tested variables, were not stated, and so the contingency coefficients were calculated and the dependences were visualised.

Degree of the statistical dependence between the observed qualitative features were assessed on the basis of the contingency coefficient $\mathrm{C}$ and Cramer's contingency coefficient V [36].

\section{$4 \quad$ Results}

Because of the limited space, thereinafter there are presented and discussed in detail only results for teaching natural science subjects (Table 2) and results for teaching foreign languages (Table 3 ). For the other groups of subjects we present only overviews of the main results (Table 4).

The contingency table (Table 2) presents recorded interaction frequencies of the responses in dependence on the respondents' segmentation factor SUB-CATEGORY OF THE TEACHING STAFF for the group of natural science subject teachers. At the same time, it shows also the main purposes for which the natural science teachers apply interactive activities and digital means in their teaching practise (the global results included in the table, i.e. results obtained for the whole group of the respondents, without their differentiation on the value of the factor SUB-CATEGORY OF THE TEACHING STAFF). The highest percentage occurrences (from the total number of 133 responses of all respondents) were recorded in case of the alternative responses $\mathrm{b}$ - to explain and exemplify new subject matter $(50.38 \%)$ and a - to invoke greater motivation to learn $(39.85 \%)$. The rest of the reasons to apply digital means into the natural science subjects teaching does not account any significance. 
Table 2. Contingency table of the frequencies of the particular responses recorded at the stated question according to the factor sub-category of the teaching staff

\begin{tabular}{|c|c|c|c|c|}
\hline \multirow[b]{2}{*}{ Teaching natural science subjects } & \multicolumn{3}{|c|}{ Sub-category of the teaching staff } & \multirow[t]{2}{*}{ Row - Totals } \\
\hline & $\begin{array}{c}\text { Primary educa- } \\
\text { tion teachers }\end{array}$ & $\begin{array}{c}\text { Lower sec. } \\
\text { education } \\
\text { teachers }\end{array}$ & $\begin{array}{c}\text { Upper Sec. } \\
\text { education } \\
\text { teachers }\end{array}$ & \\
\hline $\mathrm{a}-$ To invoke greater motivation to learn & 32 & 18 & 3 & 53 \\
\hline Column \% & $39.02 \%$ & $41.86 \%$ & $37.50 \%$ & \\
\hline Row \% & $60.38 \%$ & $33.96 \%$ & $5.66 \%$ & \\
\hline Total $\%$ & $24.06 \%$ & $13.53 \%$ & $2.26 \%$ & $39.85 \%$ \\
\hline $\begin{array}{l}\mathrm{b}-\text { To explain and exemplify new subject } \\
\text { matter }\end{array}$ & 43 & 19 & 5 & 67 \\
\hline Column \% & $52.44 \%$ & $44.19 \%$ & $62.50 \%$ & \\
\hline Row \% & $64.18 \%$ & $28.36 \%$ & $7.46 \%$ & \\
\hline Total $\%$ & $32.33 \%$ & $14.29 \%$ & $3.76 \%$ & $50.38 \%$ \\
\hline $\mathrm{c}-$ To fixate new subject matter & 3 & 3 & 0 & 6 \\
\hline Column \% & $3.66 \%$ & $6.98 \%$ & $0.00 \%$ & \\
\hline Row \% & $50.00 \%$ & $50.00 \%$ & $0.00 \%$ & \\
\hline Total $\%$ & $2.26 \%$ & $2.26 \%$ & $0.00 \%$ & $4.51 \%$ \\
\hline $\mathrm{d}$ - to apply acquired knowledge & 2 & 3 & 0 & 5 \\
\hline Column \% & $2.44 \%$ & $6.98 \%$ & $0.00 \%$ & \\
\hline Row \% & $40.00 \%$ & $60.00 \%$ & $0.00 \%$ & \\
\hline Total $\%$ & $1.50 \%$ & $2.26 \%$ & $0.00 \%$ & $3.76 \%$ \\
\hline $\mathrm{e}-$ To diagnose and grade pupils/ students & 2 & 0 & 0 & 2 \\
\hline Column \% & $2.44 \%$ & $0.00 \%$ & $0.00 \%$ & \\
\hline Row \% & $100.00 \%$ & $0.00 \%$ & $0.00 \%$ & \\
\hline Total $\%$ & $1.50 \%$ & $0.00 \%$ & $0.00 \%$ & $1.50 \%$ \\
\hline Total & 82 & 43 & 8 & 133 \\
\hline Total $\%$ & $61.65 \%$ & $32.33 \%$ & $6.02 \%$ & $100.00 \%$ \\
\hline
\end{tabular}

If we look at the obtained statistical data (Table 2) through a point of view of respondents' differentiation according to the SUB-CATEGORY OF THE TEACHING STAFF, then out of a total of 82 teachers of primary education, more than half $(52.44$ $\%$ ) said that they put interactive educational activities into the teaching natural science subject in the context of a more attractive explanation and exemplification of new subject matter and $39.02 \%$ classifies it with the aim of invoking greater motivation to learn. $3.66 \%$ of the respondents choose the way of enlisting electronic teaching resources as one of the ways of fixating new subject matter. A rather negative finding is that only $2.44 \%$ of the respondents surveyed - primary education teachers choose to deploy the interactive electronic means in the natural science subjects teaching with the aim of increasing the practical usability of acquired knowledge and skills in real situations, application of acquired knowledge (choice of answer $d$ ) or for diagnosing and grading pupils (choice of answer $e$ ).

When we look at the responses from the percentage perspective, the answers of the science teachers at the lower secondary level of education can be compared with the situation of the primary education group. Even in this group of teachers, the most frequent choice was the answer $b$, whereby teachers declared that they see the most common way of using interactive electronic educational activities as part of their pedagogical activity in the form of explaining and exemplifying new subject matter. 
From the total of 43 respondents, $44.19 \%$ chose this alternative. A consensus with a group of primary education teachers can also be found in the second most common choice of response, which was the option a (to invoke greater motivation to learn). $41.86 \%$ of lower secondary education staff identified this alternative of the answer.

As part of the evaluation of statistical data obtained from a group of science teachers at the level of upper secondary education, the percentage score is significantly higher $(62.50 \%)$ in case of the answer $b$ (explaining and exemplifying new subject matter). The second most frequently reported answer was the answer $a$ (to invoke greater motivation to learn) when out of the eight interviewed secondary and grammar school teachers, three $(37.50 \%)$ identified this alternative. From the contingency table of observed abundances (Table 2), we can declare an interesting fact that interviewed science teachers at the level of upper secondary education reported only the choice a (to invoke greater motivation to learn) or choice $b$ (to explain and exemplify new subject matter) as their answers.

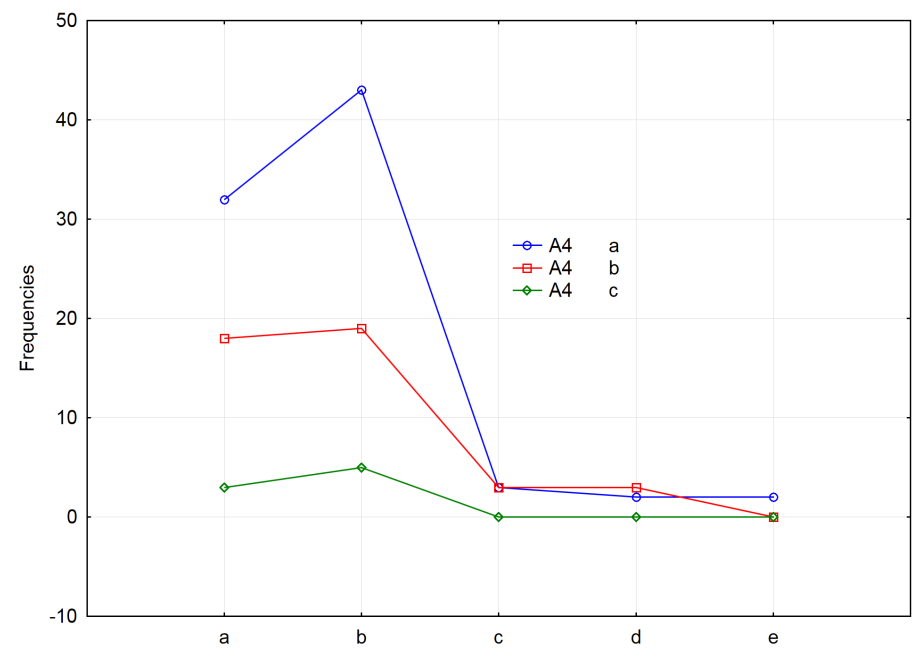

Fig. 1. Frequencies of the particular reasons $(a-e)$ to incorporate digital means in teaching process stated by the group of natural science teachers according to sub-category of the teaching staff they belong to (A4 a - primary education teachers, A4 b-lower secondary education teachers; A4 c - upper secondary education teachers)

Results of the contingency analysis for the reasoning of the most frequent incorporation of interactive educational activities and digital didactic tools in teaching natural science subjects from the point of view of the interviewed teachers depending on their belonging to the sub-category of pedagogical staff, presented in Table 2, are presented in a graphical form in Fig. 1. From the graph of interaction abundances we see that the responses in different teacher groups are more or less copied at some stages, confirming the established independence, namely that the responses of natural science subject teachers do not depend statistically from their assignment in the appropriate SUBCATEGORY OF THE TEACHING STAFF. 
The contingency table of the observed frequencies - Table 3 presents the interaction rates of the respondents' responses depending on the respondent segmentation according the factor SUB-CATEGORY OF THE TEACHING STAFF for a group of foreign languages teachers. The tabulation of the results points to the reasons and purposes of the most frequent incorporation of interactive educational activities and digital didactic resources in the foreign language teaching from the perspective of the interviewed teachers.

If we look at the results of foreign language teachers' responses to the subject matter from a global perspective, without their differentiation from the SUBCATEGORY OF THE TEACHING STAFF factor, we can observe (Table 3) that the largest group of foreign language teachers interviewed prefers the use of modern digital technologies in their teaching practice to invoke greater motivation to learn (choice of the answer $a$ ). Out of a total of 107 respondents, $44.86 \%$ of the teachers chose this option. Based on the relatively high $(28.97 \%)$ abundance, we can say that almost one third of the respondents see the most common way of using interactive educational activities to be more attractive when explaining and exemplifying new subject matter (answer $b$ ). From the interviewed sample of teachers, $15.89 \%$ include modern digital technologies in their own portfolio of teaching activities in order to fixate new subject matter (answer c). $9.35 \%$ of the foreign language teachers surveyed prefer to use interactive educational activities with the support of digital technology to apply acquired knowledge (answer $d$ ). The lowest percentage of responses was recorded in the response $e$. Only less than one percent $(0.93 \%)$ of the respondents - foreign language teachers see the possibility of diagnosing and grading pupils / students with the support of electronic didactic means. Between responses $d$ (applying acquired knowledge) and $e$ (diagnosing and grading pupils / students), the highest percentage drop of responses within the interviewed sample of teachers can be observed.

As a percentage of response scores within each of the groups of the respondents differentiated by SUB-CATEGORY OF THE TEACHING STAFF, we observe some divergence compared to the overall results described above (without any differentiation of the respondents from the above factor). Also, the frequency of responses among the interviewed groups of teachers is less varied.

Teachers from the primary education group have chosen answer $a$ - invoking greater motivation to learn, as their most frequent response to the question of the use of electronic learning activities and teaching resources. This answer was chosen by an absolute majority (51.32\%) of primary education teachers interviewed. The second most frequent response was the alternative $b$ (explaining and exemplifying new subject matter), which was $27.63 \%$. The use of digital technologies in the process of fixating new subject matter (answer $c$ ) and in applying acquired knowledge (choice d) prefers $10.53 \%$, respectively $9.21 \%$ of primary education teachers interviewed.

Lower secondary level teachers stated as the most common reasons for incorporating interactive learning resources in the teaching process explaining and exemplifying new subject matter (41.67\%), fixating new subject matter (33.33\%) and invoking greater motivation to learn $(20.83 \%)$. 
Table 3. Contingency table of the frequencies of the particular responses recorded at the stated question according to the factor sub-category of the teaching staff

\begin{tabular}{|c|c|c|c|c|}
\hline \multirow{2}{*}{ Teaching foreign languages } & \multicolumn{2}{|c|}{ Sub-category of the teaching staff } & Row - Totals \\
\cline { 2 - 4 } & $\begin{array}{c}\text { Primary } \\
\text { education } \\
\text { teachers }\end{array}$ & $\begin{array}{c}\text { Lower sec. } \\
\text { education } \\
\text { teachers }\end{array}$ & $\begin{array}{c}\text { Upper sec. } \\
\text { education } \\
\text { teachers }\end{array}$ & \\
\hline a - To invoke greater motivation to learn & 39 & 5 & 4 & 48 \\
\hline Column \% & $51.32 \%$ & $20.83 \%$ & $57.14 \%$ & \\
\hline Row \% & $81.25 \%$ & $10.42 \%$ & $8.33 \%$ & \\
\hline Total \% & $36.45 \%$ & $4.67 \%$ & $3.74 \%$ & $44.86 \%$ \\
\hline b- To explain and exemplify new subject matter & 21 & 10 & 0 & 31 \\
\hline Column \% & $27.63 \%$ & $41.67 \%$ & $0.00 \%$ & \\
\hline Row \% & $67.74 \%$ & $32.26 \%$ & $0.00 \%$ & \\
\hline Total \% & $19.63 \%$ & $9.35 \%$ & $0.00 \%$ & $28.97 \%$ \\
\hline Column \% & 8 & 8 & 1 & 17 \\
\hline Row \% & $10.53 \%$ & $33.33 \%$ & $14.29 \%$ & \\
\hline Total \% & $47.06 \%$ & $47.06 \%$ & $5.88 \%$ & \\
\hline To fixate new subject matter & $7.48 \%$ & $7.48 \%$ & $0.93 \%$ & $15.89 \%$ \\
\hline Column \% & 7 & 1 & 2 & 10 \\
\hline Row \% & $9.21 \%$ & $4.17 \%$ & $28.57 \%$ & \\
\hline Total \% & $70.00 \%$ & $10.00 \%$ & $20.00 \%$ & \\
\hline Total \% & $6.54 \%$ & $0.93 \%$ & $1.87 \%$ & $9.35 \%$ \\
\hline To apply acquired knowledge & 1 & 0 & 0 & 1 \\
\hline Row \% & $1.32 \%$ & $0.00 \%$ & $0.00 \%$ & \\
\hline Totamn $\%$ & $100.00 \%$ & $0.00 \%$ & $0.00 \%$ & \\
\hline To diagnose and grade pupils/students & $0.93 \%$ & $0.00 \%$ & $0.00 \%$ & $0.93 \%$ \\
\hline 76 & 24 & 7 & 107 \\
\hline & $71.03 \%$ & $22.43 \%$ & $6.54 \%$ & $100.00 \%$ \\
\hline
\end{tabular}

An interesting finding can be found in the group of upper secondary education teachers. The majority of the respondents $(57.14 \%)$ of this group stated response $a-$ motivational incentive of pupils to learn foreign languages, as the most frequent purpose of the use of electronically supported teaching. The interviewed secondary school teachers of foreign languages use ICT tools mainly $(28.57 \%)$ in connection with activities relevant to application of acquired knowledge (answer $d$ ). It is followed by a choice of answer $c$-fixating new subject matter by $14.29 \%$ of the secondary school teachers. Answers $b$ (explaining and exemplifying new subject matter) and $d$ (applying acquired knowledge) have not been chosen by any of the interviewed upper secondary education teachers.

Results of the contingency analysis for the most frequently stated reasoning of the incorporation of the interactive educational activities and digital didactic tools in foreign language teaching from the point of view of the interviewed teachers depending on their belonging to the sub-category of pedagogical staff, presented in table 3 , are shown in a graphical form in Fig. 2. From the graph of interaction abundances (Fig. 2) it is clear that the responses in different teacher groups (a - primary education teacher, $\mathrm{b}$ - lower secondary education teacher; c - upper secondary education teacher) are more or less copied at some stages, confirming the established independence, namely that the responses of foreign languages teachers do not depend statistically 
from their assignment in the appropriate SUB-CATEGORY OF THE TEACHING STAFF.

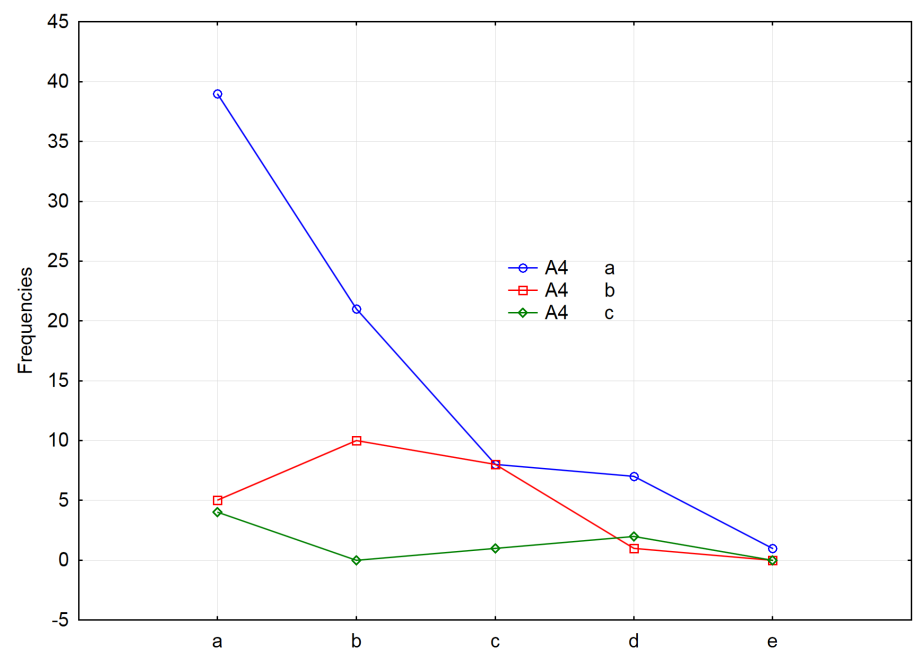

Fig. 2. Frequencies of the particular reasons $(\mathrm{a}-\mathrm{e})$ to incorporate digital means in teaching process stated by the group of foreign language teachers according to sub-category of the teaching staff they belong to (A4 a - primary education teachers, A4 b-lower secondary education teachers; A4 c - upper secondary education teachers)

The presented results could be considered to be trivial or of low importance, expecting that the rest of the results (results regarding the purposes of the use of digital means in teaching the other groups of subjects, i.e. in teaching social science subjects, foreign languages, artwork and educational subjects, and professional/vocational subjects) have been more or less the same. In fact, the results for the particular groups of the subjects differ considerably (see Table 4). In case of teachers of natural science subjects the contingency analysis showed, that independently on the factor subcategory of the teaching staff there is no difference in purposes why they use interactive activities and digital means in their practice to support efficiency of the teaching and learning processes. Obtained value of the contingency coefficient (Contingency coefficient: 0.1881279; Cramer's V: 0.135445) proves that the measure of the dependence of responses of the particular sub-groups of the respondents on their affiliation to the relevant professional sub-category of the teaching staff is weak. The same (low measure of the dependence of the purpose for which the teachers use the digital means in teaching on the sub-category of the teaching staff they belong to) can be stated also for social science teachers (Contingency coefficient: 0.212146; Cramer's V: 0.1535039$)$. For teachers teaching foreign languages, artwork and educational subjects and professional (vocational) subjects this measure is much higher, even moderate (Contingency coefficient: foreign languages 0.3729802, artwork and educational subjects 0.3075764 , vocational subjects 0.5168308 ; Cramer`s V: foreign lan- 
guages 0.2842484 , artwork and educational subjects 0.2285696 , vocational subjects 0.4268892 ).

The percentages of the relative frequencies of the particular responses presented in Table 4 refer to the total frequencies of the particular responses recorded for teaching the relevant subject category (see the explanation stated bellow Table 1). These were in case of natural science subjects 133 , in case of social science subjects 108 , in case of foreign languages 107, in case of artwork and educational subjects 100 and 18 for professional (vocational) subjects.

Table 4. Relative frequencies of the particular responses stated by different subject teachers (source: own research)

\begin{tabular}{|l|c|c|c|c|c|}
\hline \multicolumn{1}{|c|}{ Teachers of } & \multicolumn{4}{|c|}{ Relative frequencies of the particular responses } \\
\hline & $\begin{array}{c}\text { Natural } \\
\text { sciences }\end{array}$ & $\begin{array}{c}\text { Social } \\
\text { sciences }\end{array}$ & $\begin{array}{c}\text { Foreign } \\
\text { lang. }\end{array}$ & $\begin{array}{c}\text { Artwork } \\
\text { educ. } \text { s. }\end{array}$ & $\begin{array}{c}\text { profess. } \\
\text { vocat. } \text { s. }\end{array}$ \\
\hline a - To invoke greater motivation to learn & 39.85 & 30.56 & 44.86 & 60.00 & 33.33 \\
\hline b - To explain and exemplify new subject matter & 50.38 & 43.56 & 28.97 & 17.00 & 16.67 \\
\hline c - To fixate new subject matter & 4.51 & 15.74 & 15.89 & 15.00 & 38.89 \\
\hline d - To apply acquired knowledge & 3.76 & 9.26 & 9.35 & 6.00 & 11.11 \\
\hline e - To diagnose and grade pupils/students & 1.50 & 0.93 & 0.93 & 2.00 & 0.00 \\
\hline
\end{tabular}

\section{Discussion}

Alike the results of our research, conclusions of a number of other research studies confirm that the use of digital means in teaching has a significant motivational impact on pupils [18, 19, 20, 21, 22]. A research done by Brotánková [28] showed, that most of the basic school teachers (lower level of secondary schools - ISCED 2) in the Czech Republic use digital means in their teaching practice most frequently to present illustrative materials and film sequences and to present exercise assignments. Currently Hladný [34] carried out an empirical investigation to find out for what purposes secon-dary school teachers in the Czech Republic (upper level of secondary schools ISCED 3) use the digital means. The results showed that teachers use digital technologies mainly for purposes of new subject matter presentation (explanation) and completing the explanation of the new topics by different demonstrations. To a lesser extent the teachers use these means to test and asses how students' have acquired the new knowledge.

As to the natural science subjects teaching we assess the obtained results as very positive mainly because of two reasons. The first is that natural science subjects are very demanding in relation to abstract thinking and abstract imagination. Therefore, it is very desirable to bring the presented subject matter nearer to learners based on the use of the newest technologies to support their understanding of the presented topics. The second reason is may be even much more important. It regards the fact which has been proved in many researches, and it is that natural science subjects belong to the unpopular ones [37, 38, 39, 40]. In this context, we appreciate that natural science teachers have an outstanding tendency to look for new possibilities to influence pupils 
and students` interest in natural science, to cultivate their curiosity about the world around them and to form their motivation in natural science study.

The reason why elements of visualization that transform mediated learning content into a more visual form is to be included in the teaching process of natural science subjects is that in such a form the information is much easier to understand by pupils or students and the new information is more memorable [41, 42, 43]. The combination of visual and verbal component of the information increases the probability of understanding the curriculum and its application to modelled real situations through practical tasks (Mayer and Sims in [38]). Unlike printed educational content, where text contains only various static objects - images, conceptual maps and graphs - it is possible to supplement electronic study materials with dynamic objects, namely animations, audio or video sequences. This makes learning material more visible and engaging for pupils or students. However, it is always necessary to consider when and to what extent to use these interactive multimedia elements. These elements are very powerful means of clarity, motivation and remembrance, but it is nevertheless necessary to place these entities meaningfully in interactive learning activities, because improper, excessive and ill-considered use of these multimedia elements could have the opposite effect in the learning process [44].

From the results tabulation (Table 3 ) we conclude, that science education teachers do not have sufficient knowledge and skills to validate and assess pupils' learning through modern voting systems or online web tools. A great benefit of these electronic means is that the teacher can use them to greatly simplify and streamline the testing of pupils' knowledge through a supported diapason of test questions and application tasks within voting sessions (within the audience response systems). Voting equipment (audience response systems), such as ActivExpression2, SMART Response XE, QRF900 and online web applications (such as Socrative) are modern interactive devices / applications that can ask different types of questions at once to all classroom students. On the one hand, a pupil can immediately evaluate his / her success through the final summary of results, where s/he will be able to see the number of correct / incorrect answers. On the other hand, the teacher gets immediate information about pupils' knowledge and can discuss the results of voting with pupils before stating the correct answers. Voting devices can increase pupils` activity during lessons, encourage interest in the curriculum. Moreover pupils focus more on lessons because they still have to follow the lessons to answer teacher questions. The anonymity of knowledge testing in this form disrupts pupils` concern about oral examination. For these reasons, electronic verification and assessment of pupils` knowledge can be of great benefit in teaching any science subject at primary and secondary school. By using these modern means of interactive teaching, we use the pupils ' natural qualities, such as their competitiveness and playfulness. However, these didactic means of modern teaching have to be used in a considered way, so that working with them is effective and beneficial for both pupils and teachers. This is also confirmed by studies and researches on the subject $[45,46,47,48]$, which demonstrate the merits of deploying modern didactic tools in the process of teaching science subjects in regional education (ISCED 1 to ISCED 3). 
One aspect of the successful implementation of digital technologies in the teaching process is pupils' attitudes towards digital technology aided teaching. It is generally known that most of today's youth has mostly a positive relationship with technology. Therefore, most of our respondents - foreign language teachers, especially from the primary and upper secondary education sample - consider the integration of electronic learning activities and didactic digital resources into teaching as motivating for pupils. Already the very presence of technology is considered as a motivating factor in teaching. Therefore, respondents in our sample of foreign language teachers believe that deploying electronic learning activities and didactic digital resources in the process of teaching foreign languages can make learning more attractive to pupils. Some teachers are worried about the gradual decline in pupils' interest in their teaching, and therefore they are trying to make their lessons more interesting. Therefore, they consider these digital means and interactive educational activities as effective resources of making learning more attractive. Despite the fact that technologies do not contribute to teaching as such, current pedagogy considers digital means, when appropriately didactically applied in teaching, to be useful means of implementing teaching activities.

Especially great potential is offered by the internet to support current foreign language teaching. Its use can be beneficial both thanks to its technical advantages, and at the same time the internet also offers interesting pedagogical possibilities. From a pedagogical point of view, internet tools are considered to be suitable means to support the didactic-methodological principles of contemporary foreign language teaching. The Web serves as a source of information presented in different sensory modes, as a communication tool, as a collaborative tool for people around the world and as a pro-duct publishing tool. E-learning activities from the internet can be tailored to the needs of the pupils and teaching goals, archived and edited for further use. From the freely available resources on the internet supporting simultaneous foreign language teaching, it is possible to mention an electronic dictionary, for example when working with authentic texts, or authoring (online) software for creating interactive exercises. The internet also provides a range of other resources that can be used as supportive learning materials. Foreign language teachers use the internet primarily for acquiring foreign language texts, either linear or hypertext. There are also portals for foreign language teachers, where texts are broken down by language level and thematic areas. Teachers can then process the found authentic materials didactically for their use, sometimes the offer is even supplemented by activities that have already been taught and, related to the published teaching materials.

Digital resources are a working tool not only for teachers but also for pupils in the creative process of a product. One example is the use of a text editor for writing essays, or the preparation of electronic presentations, which is the final product of the activity and a basis for verbal presentation of a predetermined topic by the pupil. In the stages of the preparation of background materials, on which the presentation will be based, the internet is again used by pupils. Digital resources also play a significant role in the processing of photos and images through freely downloadable graphic environments that can be part of the final product, such as a presentation or output to a processed project. 
To test the knowledge of grammar, vocabulary, and the level of primary receptive speech skills, interactive language exercises are used by foreign language teachers to fix the presented subject matter that is mostly part of a foreign language textbook, although some teachers create it themselves using software applications that are part of different interactive hardware solutions, or use free online exercises. Most of the exercises are focused on practicing grammar, some equally on vocabulary and receptive speech skills - listening and reading comprehension. In most cases, in the lesson, or as part of home preparation of pupils, the following assignment types are used pupils assign words or phrases to pictures, the end of sentences to their beginnings, the forms of possessive replacements to the nouns of different gender, answers to letters to letters, and so on. Discriminatory types of exercises are also used - pupils choose the correct grammatical form from two or three possible options, logical continuation of the menu dialogue, pictures related to the text being listened to, the right variants of the listened / read story, etc. In addition, the complementary types of tasks are also used extensively in foreign language teaching - pupils fill out the missing correct form (endings, whole words). Last but not least, there are also exercises to find information in the text where pupils identify the information they need by clicking on it, or exercises designed to construct a dialogue in which pupils create a dialogue by choosing a phrase, for example, from three options, or assigning parts of text / images in the correct order. All the types of exercises and tasks listed above are essentially closed exercises that allow only a predefined correct solution. The results are usually statistically evaluated. Some interactive exercises respond to the pupil's solution immediately and do not allow him to answer incorrectly - the wrong expression cannot be assigned, it is automatically returned to the menu and highlighted in colour. Other programs allow to solve the whole exercise and then run a check. The computer will identify wrong solutions and write / offer the right solution. At the same time, it calculates the percentage of pupils' results for these exercises and tasks.

Without the need for generalization, we can state that modern digital means are used in many different ways in the work of foreign language teachers and that they have various didactic functions in their teaching work. Didactic functions result from the didactic potential of the digital resources used. However, it is crucial for the teaching of foreign languages and its outcomes how the teacher uses the potential offered to achieve learning objectives.

\section{Conclusion}

The obtained results have proved a dependence of the purposes for which teachers use the digital means during their lessons on the character of the taught subjects (there are differences among the main significant purposes to use the digital means in teaching the respective groups of the subjects to increase efficiency of their teaching). On the other hand, the dependence of the purposes for which the teachers use the digital means in their teaching practice on the sub-category of the teaching staff to which a teacher belongs has not been proved. These results should be taken into consideration at creation curricula of teacher trainees` didactic-technological preparation as well as 
at creation curricula of professional development courses focused on upgrading inservice teachers` didactic-technological competences.

\section{Acknowledgement}

This work has been supported by the Cultural and Educational Grant Agency of the Ministry of Education, Science, Research and Sport of the Slovak Republic under the project No. KEGA 041UK-4/2017 and by the Slovak Research and Development Agency under the contract No. APVV-14-0446 and No. APVV-15-0378.

\section{$8 \quad$ References}

[1] OECD. Talis 2013 Results: An International Perspective on Teaching and Learning, OECD Publishing, 2014. Available: http://www.keepeek.com/Digital-Asset-Management/ oecd/education/talis-2013-results 9789264196261-en\#page1 https://doi.org/10.1787/9789 $\underline{\text { 264196261-en }}$

[2] M. Esteves, A. Pereira, N. Veiga, R. Vasco, A. Veiga, "The Use of New Learning Technologies in Higher Education Classroom: A Case Study", International Journal of Engineering Pedagogy, vol. 8, no. 2, pp. 115-127, 2018. https://doi.org/10.3991/ijep.v8i2.8146

[3] S. Riahi, A. Riahi, "The Pedagogy of Higher Education: How to Evaluate the Quality of Training in Morocco to Improve it", International Journal of Engineering Pedagogy, vol. 8, no. 1, pp. 92-108, 2018. https://doi.org/10.3991/ijep.v8i1.7984

[4] J. Anderson, T. van Weert, and C. Duchâteau, Information and Communication Technology in Education: A Curriculum for schools and Programme of Teacher Development. Paris: Division of Higher Education, Paris: UNESCO, 2002.

[5] B. Kasáčová, et al., Profesijný rozvoj učitel'a. Prešov: MPC, 2006.

[6] B. Kosová, et al., Vysokoškolské vzdelávanie učitelov. Vývoj, analýza, perspektívy. Banská Bystrica: Pedagogická fakulta Univerzity Mateja Bela, 2012.

[7] B. Kosová, A. Tomengová, et al., Profesijná praktická príprava budúcich učitelov. Banská Bystrica: Belianum, 2015.

[8] R. J. Krumsvik, "Digital competence in Norwegian teacher education and schools", Högre utbildning, vol. 1, no. 1, pp. 39-51, 2011.

[9] A. Drigas, M. Karyotaki, "Learning Tools and Applications for Cognitive Improvement", International Journal of Engineering Pedagogy, vol. 4, no. 3, pp. 71-77, 2014. https://doi.org/10.3991/ijep.v4i3.3665

[10] J. Záhorec, A. Hašková, M. Munk, "Particular results of a research aimed at curricula design of teacher training in the area of didactic technological competences", International Journal of Engineering Pedagogy, vol. 8, no. 4, pp. 16-31, 2018. https://doi.org/10.3991/ijep.v8i4.8184

[11] M. Klement, J. Dostál, J. Kubrický, and K. Bártek, ICT nástroje a učitelé: adorace, či rezistence? Olomouc: Univerzita Palackého, 2017. https://doi.org/10.5507/pdf.17.24450926

[12] K. McKnight, K. O'Malley, R. Ruzic, M. K. Horsley, J. J. Franey, K. Bassett, “Teaching in a Digital Age: How Educators Use Technology to Improve Student Learning", Journal of Research on Technology in Education, vol. 48, no. 3, pp. 194-211, 2016. https://doi.org/10.1080/15391523.2016.1175856 
[13] H. Montrieux, R. Vanderlinde, T. Schellens, L. De Marez, "Teaching and Learning with Mobile Technology: A Qualitative Explorative Study about the Introduction of Tablet Devices in Secondary Education", PLoS ONE, vol. 10, no. 12, pp. 1-17, 2015. https://doi.org/10.1371/journal.pone.0144008

[14] O. Neumajer, L. Rohlíková, and J. Zounek, Učíme se s tabletem: využití mobilních technologii ve vzdélávání. Praha: Wolters Kluwer, 2015.

[15] M. Skutil, M. Maněnová, L. Čermáková, "ICT as a Didactic Tool and Its Use in the Educational Process", International Journal of e-Education, e-Business, e-Management and eLearning, vol. 3, no. 4, pp. 285-288, 2013. https://doi.org/10.7763/ijeeee.2013.v3.241

[16] A. Sangrà, M. González-Sanmamed, "The role of information and communication technologies in improving teaching and learning processes in primary and secondary schools", Research in Learning Technology, vol. 18, no. 3, pp. 207-220, 2010. DOI: 10.1080/09687769.2010.529108. https://doi.org/10.3402/rlt.v18i3.10764

[17] R. Dofková, and M. Uhlírová, "Next generation classroom as an instrument for motivation in mathematics", INTED2016 Proceedings. Valencie: IATED, 2016, pp. 3178-3183. https://doi.org/10.21125/inted.2016.0174

[18] K. Bártek, D. Nocar, and J. Wossala, "ICT Training of Mathematics Teachers in the Context of Their Current Educational Needs", ICERI 2016 Proceedings. Seville: IATED, 2016, pp. 336-341. https://doi.org/10.21125/iceri.2016.1081

[19] B. Clarke, and S. Svanaes, An update literature review on the use of tablets in education. Tablets for Schools. UK: Family Kids \& Youth, 2014.

[20] M. Klement, "Současná situace ve využití ICT na základních školách”, DIDMATTECH 2014. Olomouc: Vydavatelství UP, 2014, pp. 305-312.

[21] A. D. Olofsson, J. O. Lindberg, G. Fransson, T. E. Hauge, "Uptake And Use of Digital Technologies in Primary And Secondary Schools - a Thematic Review of Research",Nordic Journal of Digital Literacy, vol. 6, no. 4, pp. 207-225, 2011.

[22] M. Harris, "Teacher Efficacy Beliefs: Understanding the Relationship Between Efficacy and Achievement in Urban Elementary Schools", UC Berkeley. 2010, ProQuest ID: Harris berkeley_0028E_10955. Available: https://escholarship.org/uc/item/44h29077

[23] C. Kyriacou, Kličové dovednosti učitele: Cesty k lepšímu vyučování (Essential Teaching Skills). Praha: Portál. 2012.

[24] M. Uhlírová, "Primary School Teacher Typology According to the Level of ICT Implementation in Teaching Mathematics", L. Gómez Chova, A. López Martínez, I. Candel Torres (eds) EDULEARN14 Proceedings. Valencie: IATED Academy, 2014, pp. 12381245.

[25] M. Havelka, "Data Logging - prostředek integrace prvků ICT do výuky na 2. stupni ZŠ a na SŠ”, Informatika v škole, vol. 38, 2011.

[26] E. Petlák, Pedagogicko-didaktická práca učitel'a. Bratislava: IRIS, 2007.

[27] J. Vaníček, "Př́íprava učitelů na používání technologií při výuce matematiky a její rizika", Pedagogika, vol. 60, no. 2, pp. 127-136, 2010.

[28] Z. Brotánková, Využití interaktivních médií ve výuce českého jazyka. Liberec: Technická univerzita, Fakulta přírodovědně-humanitní a pedagogická, 2016.

[29] D. Kostrub, "Tri perspektívy nazerania na didaktické využitie počítača (a IKT) vo výučbe v školách”, Spoločnost' pre predškolskú výchovu, 2012, Available: http://www.spvzv.sk/products/tri-perspektivy-nazerania-na-didakticke-vyuzitie-pocitaca-a-ikt-vo-vyucbev-skolach-dusan-kostrub. https://doi.org/10.15584/di.2015.10.13

[30] J. Chromý, Materiálni didaktické prostředky v informační společnosti. Praha: Verbum, 2011. 
[31] J. Hlavatý, Didaktická technika pro učitele. Praha: Vysoká škola chemicko-technologická v Praze, 2002.

[32] M. Hausner, "Strategie rozvoje ICT z pohledu vedení školy”, (II. část), Sborník přikladů dobré praxe využití ICT ve školách. Nový Jičín, 2011.

[33] J. Novák, Media and digital technologies in primary school education (Bakalárska práca). Praha: Univerzita Karlova v Praze, Fakulta sociálních věd, 2016.

[34] M. Hladný, Využití digitálních technologii na středních školách. Zlín: Univerzita Tomáše Bati, Fakulta humanitních studií, 2018. https://doi.org/10.7441/soced.2017.05.01.04

[35] Law No. 317/2009 on Teaching Staff and Specialists and its Amendments. Available: https://www.minedu.sk/data/att/2918.pdf

[36] J. Cohen, "Statistical power analysis for the behavioral sciences," (2nd ed.), 1988. Statistika pre prax. 2007.

[37] B. Akarsu, "Upper Secondary School Pupils' Attitudes towards Natural Science", European Journal of Physics Education, vol. 4, no. 1, pp. 59-68, 2017.

[38] T. Odcházelová, "Role multimédií ve výuce př́rodních věd", Scientia in educatione, vol. 5, no. 2, pp. 2-12, 2014.Available: http://www.scied.cz/index.ph $\mathrm{p} /$ scied/article/viewFile/93/97

[39] V. Lamanauskas, "Natural Science Education Importance in Adolescence", Journal of Baltic Science Education, vol. 12, no. 4, pp. 396-398, 2013.

[40] A. T. Yazachew, "Students' Attitude Towards Natural Science in Debre Markos Town Primary Schools", International Journal of Technology Enhancements and Emerging Engineering Research, vol. 2, no. 1, pp. 18-29, 2013.

[41] G. Aleandri, and L. Refrigeri, "Lifelong Education and Training of Teacher and Development of Human Capital", Global conference on linguistics and foreign language teaching (LINELT-2014). Elsevier, Procedia - Social and Behavioral Sciences, 2014, vol. 136. https://doi.org/10.1016/j.sbspro.2014.05.372

[42] L. Koreňová, "What to Use for Mathematics in High School: PC, Tablet or Graphing Calculator?", International Journal for Technology in Mathematics Education, vol. 22, no. 2, pp. 59-64, 2015.

[43] J. Gunčaga, and R. Janiga, "Virtual Labs and Educational Software as a Tool for more Effective Teaching STEM Subjects", The Third International Conference on Computer Science, Computer Engineering, and Education Technologies / ed. Jacek Stando. [1st ed.]. Łodz: Łodz University of Technology, 2016. pp. 1-12.

[44] D. Nocar, "Advantages and disadvantages of electronic study supports in comparison with printed study supports", XXIII. mezinárodní kolokvium, Brno, 2005 Available: http://www.scied.cz/index.php/scied/article/viewFile/93/97

[45] A. Bray, B. Tangney, "Technology usage in mathematics education research - A systematic review of recent trends", Computers \& Education, vol. 114, Issue C, Nov., pp. 255-273, 2017. https://doi.org/10.1016/j.compedu.2017.07.004

[46] F. Látal, M. Michejdová, "Elektronické hlasovací zařízení”, Matematika - fyzika - informa-tika, vol. 23, no. 4, pp. 313-319, 2014.

[47] D. Alt, "Science teachers' conceptions of teaching and learning, ICT efficacy, ICT professional development and ICT practices enacted in their classrooms", Teaching and Teacher Education: An International Journal of Research and Studies, vol. 73, no. 1, pp. 141-150, 2018, https://doi.org/10.1016/j.tate.2018.03.020

[48] E. P. Brooks, N. Borum, and T. Rosenørn, "Designing Creative Pedagogies Through the Use of ICT in Secondary Education", International Conference on Education \& Educational Psychology 2013 (ICEEPSY 2013). Procedia - Social and Behavioral Sciences, vol. 112, 2014, pp. 35-46. https://doi.org/10.1016/j.sbspro.2014.01.1137 


\section{Authors}

Ján Záhorec, Dr., Ph.D. works as an assistant professor at the Department of Didactics of Natural Sciences in Primary Education, Faculty of Education, Comenius University in Bratislava. The areas of his research are informatics and electronically supported learning. He is interested in developing fully interactive educational environments and e-learning technologies and their applications for specific purposes into the educational process at various levels of the school system. He is the author of more than 83 publications (articles in reviewed journals, proceedings of conferences, chapters in monographs, teaching texts) published in Slovakia and abroad.

Alena Hašková, Prof., Dr., Ph.D. is a professor of Technology of Education. She works at the Department of Technology and Information Technologies at the Faculty of Education, Constantine the Philosopher University in Nitra. Her primary interests are methodology of technical subject teaching, ICT applications in education, development of educational environments and their use for specific purposes and optimization of school management. She is the author and co-author of 11 monographs, 10 textbooks and more than 270 articles published in Slovakia and abroad.

Adriana Nagyová, Mgr., Ph.D. works as an assistant professor at the Department of Pedagogy and Social Pedagogy, Faculty of Education, Comenius University in Bratislava. Her scientific research activities are focused on issues of school management and disciplinary didactics. She also focuses on design, development and implementation of interactive solutions for supporting and modernization of education. She is the author of more than 35 publications (articles in reviewed journals, proceedings of conferences, terms in a terminology and explanatory dictionary of school management) published in Slovakia and abroad.

Article submitted 2019-06-19. Resubmitted 2019-06-21. Final acceptance 2019-06-21. Final version published as submitted by the authors. 